\title{
Article
}

\section{The Effect of Chromium on Photosynthesis and Lipid Accumulation in Two Chlorophyte Microalgae}

\author{
Khawaja Muhammad Imran Bashir ${ }^{1}{ }^{(0}$, Hyeon-Jun Lee ${ }^{2}$, Sana Mansoor ${ }^{3}{ }^{\circledR}$, Alexander Jahn ${ }^{1}{ }^{(\mathbb{D}}$ and \\ Man-Gi Cho ${ }^{4, *}$ \\ 1 German Engineering Research and Development Center, LSTME-Busan, Busan 46742, Korea; \\ imranagrarian3@gmail.com (K.M.I.B.); alexander.jahn@lstme.org (A.J.) \\ 2 Department of Chemical and Biological Engineering, Institute of Fluid Mechanics, \\ Friedrich-Alexander-Universität Erlangen-Nürnberg Busan Campus, Busan 46742, Korea; \\ why123why123@naver.com \\ 3 Department of Environmental Engineering, College of Engineering, Dong-A University, Busan 49315, Korea; \\ sanamansoorahmad@gmail.com \\ 4 Department of Biotechnology, Division of Energy and Bioengineering, Dongseo University, \\ Busan 47011, Korea \\ * Correspondence: mgcho@gdsu.dongseo.ac.kr; Tel.: +82-51-320-2662
}

Citation: Bashir, K.M.I.; Lee, H.-J.; Mansoor, S.; Jahn, A.; Cho, M.-G. The Effect of Chromium on

Photosynthesis and Lipid Accumulation in Two Chlorophyte Microalgae. Energies 2021, 14, 2260. https://doi.org/10.3390/en14082260

Academic Editors: Jack Legrand and Makareviciene Violeta

Received: 4 March 2021

Accepted: 16 April 2021

Published: 17 April 2021

Publisher's Note: MDPI stays neutral with regard to jurisdictional claims in published maps and institutional affiliations.

Copyright: (c) 2021 by the authors. Licensee MDPI, Basel, Switzerland. This article is an open access article distributed under the terms and conditions of the Creative Commons Attribution (CC BY) license (https:/ / creativecommons.org/licenses/by/ $4.0 /)$.

\begin{abstract}
Heavy metals have adverse effects on microalgae metabolism and growth. Photosynthesis and lipid profile are quite sensitive to heavy metal toxicity. The impact of hexavalent chromium$\mathrm{Cr}(\mathrm{VI})$ on photosynthesis and lipid accumulation in Mucidosphaerium pulchellum and Micractinium pusillum exposed to different concentrations $\left(0-500 \mu \mathrm{g} \mathrm{L}^{-1}\right)$ was investigated for 11 days. A significant $(p<0.05)$ increase in lipid content was observed with increasing $\mathrm{Cr}(\mathrm{VI})$ concentration. However, growth was suppressed at higher concentrations exceeding $100 \mu \mathrm{g} \mathrm{L}{ }^{-1}$. Addition of $\mathrm{Cr}(\mathrm{VI})$ in the cell culture medium showed a negative effect on quantum yield $\left(F_{v} / F_{m}\right)$, and a photosynthetic inhibition of $>65 \%$ was noted in both species at $500 \mu \mathrm{g} \mathrm{L}^{-1}$. However, the lipid gravimetric analysis presented inner cell lipid content up to $36 \%$ and $30 \%$ of dry weight biomass for M. pulchellum and M. pusillum, respectively. The fatty acids profiles of both microalgae species showed higher levels of hexadecenoic acid as well as $\omega 3, \omega 6$, and $\omega 7$ fatty acids. The effect of $\mathrm{Cr}(\mathrm{VI})$ on photosynthesis and lipid accumulation in both microalgae species was concentration and exposure time dependent. This shows that an appropriate concentration of $\mathrm{Cr}(\mathrm{VI})$ in culture medium could be beneficial for higher lipid accumulation in freshwater eukaryotic microalgae species.
\end{abstract}

Keywords: fatty acids; freshwater microalgae; growth kinetics; heavy metal; Micractinium pusillum; Mucidosphaerium pulchellum; photosynthesis; toxicity

\section{Introduction}

The use of microalgae in the pharmaceutical, medical and food industries is increasing due to their no reported side effects on human health. Thus, it is necessary to investigate microalgae growth parameters and potential growth inhibitors [1]. Heavy metals, antibiotics and herbicides are toxic to microalgae even at low concentrations; however, to a certain extent, microalgae could adapt to a contaminated environment [2-5]. Microalgae, one of the primary producers in the marine ecosystem, change their composition such as fatty acids, lipids, pigments and exopolymers when exposed to heavy metal contamination $[6,7]$. Therefore, investigating the adaptation and survival of microalgae species in a contaminated environment is imperative [8-11]. Investigating the effect of heavy metal toxicity on growth and photosynthetic activity of microalgae could substantially influence overall ecological risk evaluation of heavy metals.

Rapid industrialization and urbanization have increased the environmental presence of heavy metals, which is causing water pollution, and it is becoming a serious issue 
worldwide [12]. Several methods have been developed to reduce the concentration of heavy metals from wastewater [13]; however, non-biodegradable heavy metals resist bioremediation and show long environmental persistence times [14,15], which is posing a serious threat for the biotic life. Heavy metals are abundantly available in nature. Unlike other heavy metals such as zinc $(\mathrm{Zn})$ and copper $(\mathrm{Cu})$, chromium $(\mathrm{Cr})$ is not required for plant respiration or growth. However, due to rapid industrialization, an abundant quantity of $\mathrm{Cr}$ is being dumped into the water, causing unfavorable effects on animals and plants [12] Furthermore, $\mathrm{Cr}$ toxicity is form-dependent, with hexavalent chromium- $\mathrm{Cr}(\mathrm{VI})$-being significantly more toxic to humans than trivalent chromium- $\mathrm{Cr}$ (III) [16]. Trace amounts of $\mathrm{Cr}(\mathrm{III})$ are needed daily for adult humans [17]. On the other hand, $\mathrm{Cr}(\mathrm{VI})$ has carcinogenic and mutagenic effects on humans [17]. Severe acute effects including gastrointestinal disorders, hemorrhagic diathesis and convulsions could occur when ingesting $1-5 \mathrm{~g}$ of chromate $[17,18]$.

The exposure of microalgae to heavy metals could cause inhibited growth, suppressed cell division, reduced photosynthesis, and restrained enzymatic activity [19-21]. Advancement in chlorophyll fluorescence technology has made easier to analyze the photosynthesis processes, which has enabled researchers in finding new factors affecting photosynthesis. Even though the impact of heavy metals on microalgae has gained considerable attention and has been extensively reported, the effects of $\mathrm{Cr}(\mathrm{VI})$ toxicity on Chlorophyte microalgae species Mucidosphaerium pulchellum (formerly Dictyosphaerium pulchellum) and Micractinium pusillum have not been yet reported.

In the present study, the toxic effects of heavy metal hexavalent chromium on growth and modulated fluorescence of freshwater eukaryotic non-model microalgae species M. pulchellum and M. pusillum were analyzed and compared. Furthermore, the effect of chromium on lipid accumulation and lipid composition was also investigated.

\section{Materials and Methods}

\subsection{Microalgae Culture and Treatment}

The eukaryotic freshwater microalgae species Mucidosphaerium pulchellum and Micractinium pusillum (phylum Chlorophyta, class Trebouxiophyceae) were obtained from the Korea Marine Microalgae Culture Center (KMMCC), Busan, Korea. Stocks were maintained on modified-AF6 agar slants [22]. The microalgae species were cultured in $250 \mathrm{~mL}$ flask bioreactors containing modified-AF6 medium [23], without citrate and ETDA, at a constant light intensity of $50 \pm 2 \mu \mathrm{mol}$ photons $\mathrm{m}^{-2} \mathrm{~s}^{-1}, 25 \pm 2{ }^{\circ} \mathrm{C}$ temperature and $50 \%$ humidity. The effects of potassium dichromate $\left(\mathrm{K}_{2} \mathrm{Cr}_{2} \mathrm{O}_{7}\right.$, Yakuri Pure Chemicals, Osaka, Japan), a hexavalent form of chromium- $\mathrm{Cr}(\mathrm{VI})$, on photosynthesis and lipid accumulation at different concentrations ( 0 to $500 \mu \mathrm{g} \mathrm{L}^{-1}$ ) were investigated. All experiments were repeated at least three times.

\subsection{Determination of Microalgae Growth Performance}

Growth performance was determined by measuring the cell densities, optical densities and growth rates. Growth rates were calculated using the cell densities. Briefly, on each sampling day, $5 \mathrm{~mL}$ sample was collected from each culture flask after a thorough hand mixing and cell densities were determined using hemocytometer (Paul Marienfeld $\mathrm{GmbH}$ \& Co. KG, Lauda-Königshofen, Germany) under a light microscope at a magnification of $400 \times$. Furthermore, optical density at $750 \mathrm{~nm}\left(\mathrm{OD}_{750}\right)$ was recorded using UV-VIS spectrophotometer (WPA Biowave II, Biochrom Ltd., Cambridge, UK) on every alternating day [5].

\subsection{Measurement of Toxicity, Modulated Fluorescence and Photosynthetic Inhibition}

The sensitivity of M. pulchellum and M. pusillum in media supplemented with different concentrations of $\mathrm{Cr}(\mathrm{VI})$ was evaluated by toxy-PAM dual channel yield analyzer (Heinz Walz GmbH, Effeltrich, Germany) [5]. This toxicity analyzer is extremely sensitive to chlorophyll fluorescence and uses saturation pulse method to determine the effective 
fluorescence yield of photosystem II (PSII) [24,25]. To induce an equilibrium state for the photosynthetic electron transport, microalgae samples were dark adopted, by placing in complete dark for $30 \mathrm{~min}$ before analysis, and fluorescence intensity was measured using low intensity modulated light to avoid the reduction of the PSII primary electron acceptor $\left(Q_{A}\right)$ [24].

Fluorescence intensity of microalgae cells excited by toxy-PAM blue light was measured at $650 \mathrm{~nm}$. The minimal fluorescence level $\left(F_{0}\right.$; fluorescence measured shortly before the application of a saturation pulse) and the maximal fluorescence level $\left(F_{m}\right.$; fluorescence measured during a saturation pulse) were recorded, and the effective overall quantum yield $(Y)$ of PSII was calculated using the following equation [24]:

$$
\text { Quantum Yield }(Y)=\left(F_{m}-F_{0}\right) / F_{m}=F_{v} / F_{m}
$$

Relative photosynthetic inhibition was calculated using the following equations [5].

$$
\begin{aligned}
& \text { Relative Photosynthetic Inhibition } \%=100(Y 2-Y 1) / Y 2(Y 1<Y 2) \\
& \text { Relative Photosynthetic Inhibition } \%=100(Y 2-Y 1) / Y 2(Y 1>Y 2)
\end{aligned}
$$

\subsection{Lipid Extraction}

The tested microalgae species were grown in modified-AF6 medium supplemented with different concentrations of $\mathrm{Cr}(\mathrm{VI})$ until pre-stationary phase, and total lipids were extracted following the Bligh and Dyer method with slight modifications [26]. Briefly, microalgae cells were harvested by centrifugation at $4{ }^{\circ} \mathrm{C}$ and $5000 \times g$ for $20 \mathrm{~min}$. Pellets were rinsed with distilled water and freeze-dried at $-85^{\circ} \mathrm{C}$. Dried pellets were weighed, dissolved in $10 \mathrm{~mL}$ of methanol: chloroform (2:1) solution and homogenized using ULTRA TURRAX Homogenizer (IKA-Werke GmbH \& Co. KG, Staufen, Germany at 16,000 rpm for $2 \mathrm{~min}$. Samples were incubated overnight in the dark at room temperature. The following day, $6 \mathrm{~mL}$ distilled water and $3 \mathrm{~mL}$ chloroform was added in each tube, inverted carefully and centrifuged at $5000 \times g$ for $10 \mathrm{~min}$. The lower organic phase was transferred to a new $15 \mathrm{~mL}$ falcon tube, freeze-dried overnight at $-85^{\circ} \mathrm{C}$ and dried for another $4 \mathrm{~h}$ at $50{ }^{\circ} \mathrm{C}$ in a dry-oven until all the solvent was evaporated. The tubes were weighed, and total lipid content in each sample was calculated.

\subsection{Fatty Acid Analysis}

Total fatty acids extracted from M. pulchellum and M. pusillum were analyzed by gas chromatography (GC) of fatty acid methyl esters (FAMEs) prepared according to Ichihara and Fukubayashi [27], with slight modifications. Briefly, total fatty acids were trans-methylated with $3 \mathrm{~mL}$ of methanolic-hydrochloric acid solution at $90{ }^{\circ} \mathrm{C}$ for $1 \mathrm{~h}$. Samples were cooled at room temperature. A total of $1 \mathrm{~mL}$ hexane and $1 \mathrm{~mL}$ distilled water was added to the extracts and mixed well by vortex. The upper fatty acid layer was separated by centrifugation at $3000 \times g$ for $6 \mathrm{~min}$ and collected in GC vials.

GC analysis of FAMEs was conducted using PerkinElmer Clarus 680 Gas Chromatograph (PerkinElmer, Inc., Waltham, MA, USA) equipped with $30 \mathrm{~m} \times 20 \mu \mathrm{m} \times 25 \mathrm{~mm}$ SP-2380 capillary column (Sigma-Aldrich, Co., St. Louis, MO, USA). The initial oven temperature was set to $140{ }^{\circ} \mathrm{C}$ and increased at a rate of 4 to $240^{\circ} \mathrm{C}$. Helium (He) was used as a carrier gas at a flow rate of $1 \mathrm{~mL} / \mathrm{min}$. Injection temperature and volume were set at $230^{\circ} \mathrm{C}$ and $1 \mu \mathrm{L}$, respectively. Fatty acids were identified by comparison with retention times of 37-component FAME mix standards (Sigma-Aldrich) and were expressed as $\mathrm{mg} / \mathrm{L}$. The corresponding fatty acids were further cross checked with the instrument database containing the NIST ${ }^{\circledR}$ library [28].

\subsection{Statistical Analysis}

The statistical significance of the results was calculated using Analysis of Variance via SPSS ver. 27 (SPSS, Chicago, IL, USA). The significance among the samples was assessed 
using Duncan's multiple-range test and the results were considered statistically significant at $p<0.05$.

\section{Results}

\subsection{Influence of Chromium on Microalgal Growth}

The culture medium, modified-AF6 medium, was supplemented with different concentrations of $\mathrm{Cr}(\mathrm{VI})$ ranging from 0 to $500 \mu \mathrm{g} \mathrm{L}{ }^{-1}$, and their effects on growth parameters were investigated for 11 days. The microalgae species M. pulchellum and M. pusillum showed significant sensitivities to the tested $\mathrm{Cr}(\mathrm{VI})$ concentrations as indicated by the optical density and cell density values. As shown in Figure 1, Cr concentrations, $0-100 \mu \mathrm{g} \mathrm{L}^{-1}$, showed normal cell densities whereas the concentrations exceeding $100 \mu \mathrm{g} \mathrm{L} \mathrm{L}^{-1}$ here, $250 \mu \mathrm{g} \mathrm{L}^{-1}$ and $500 \mu \mathrm{g} \mathrm{L}^{-1}$, showed a decline in growth after day 7. Both microalgae cultures showed reduced growth as compared to the control; it could be due to the possible toxicity of the $\mathrm{Cr}(\mathrm{VI})$. Interestingly, growth measurement study at absorbance of $750 \mathrm{~nm}$ $\left(\mathrm{OD}_{750}\right)$ showed similar results with the cell densities (Figure 2).

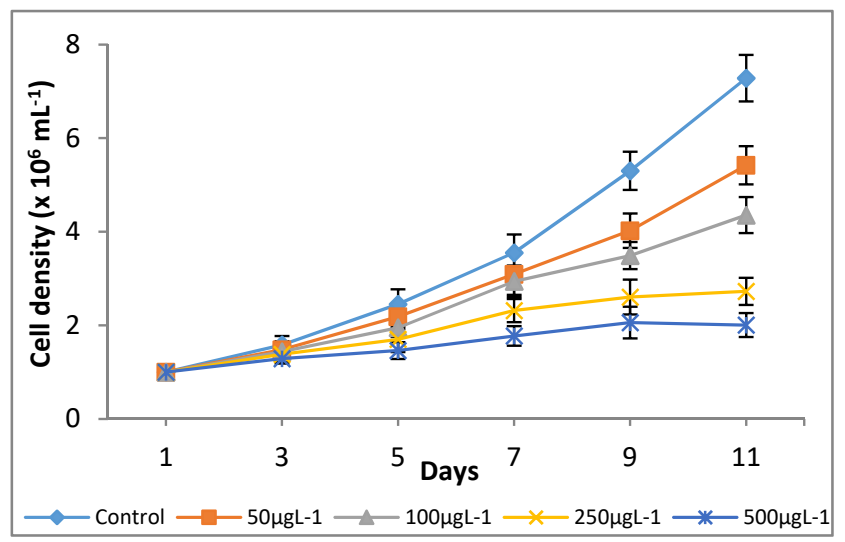

(a)

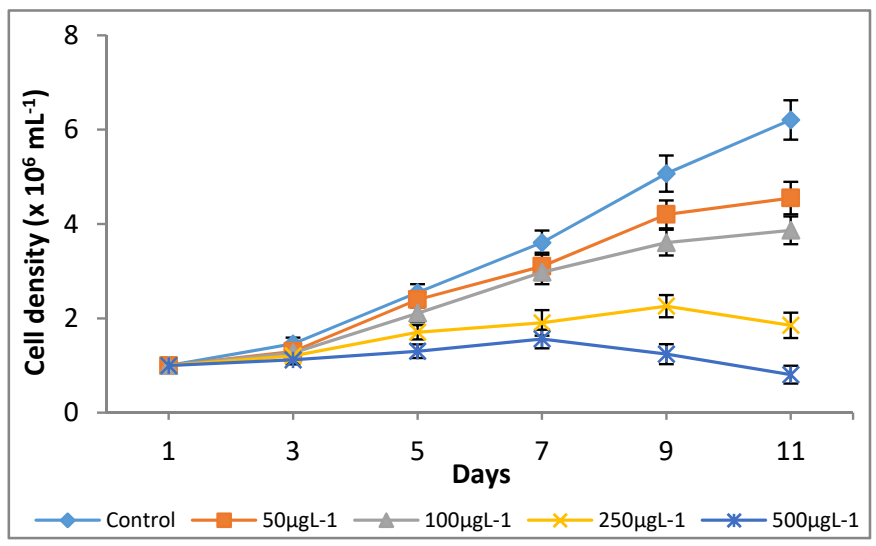

(b)

Figure 1. Effect of $\mathrm{Cr}(\mathrm{VI})$ on cell density of (a) M. pulchellum and (b) M. pusillum. X-axis represents culturing days and the cell densities $\left(\times 10^{6} \mathrm{~mL}^{-1}\right)$ are shown along the $y$-axis. Data are means $\pm \mathrm{SE}, n=3$.

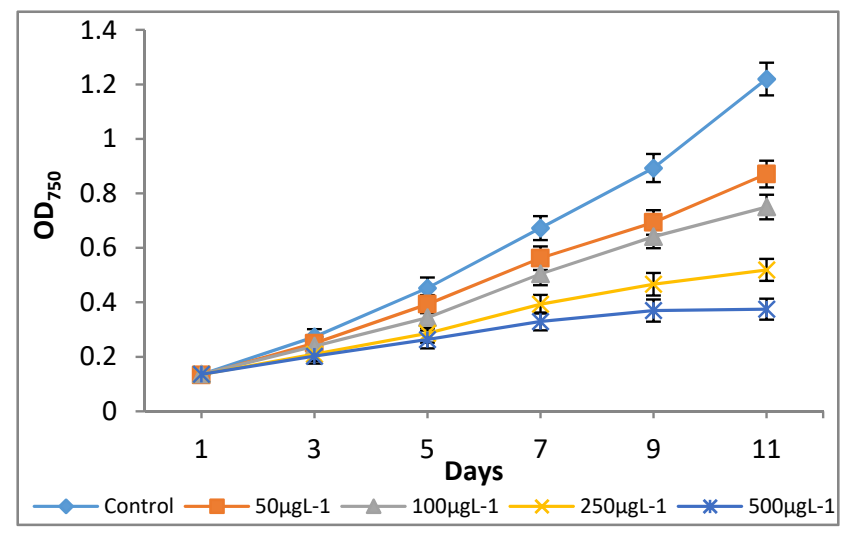

(a)

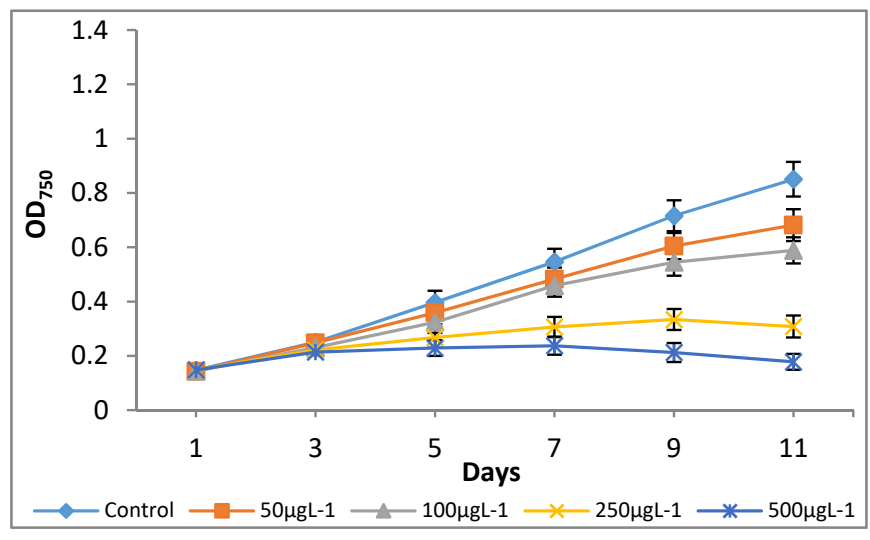

(b)

Figure 2. Effect of $\mathrm{Cr}(\mathrm{VI})$ on optical density of (a) M. pulchellum and (b) M. pusillum. X-axis represents culturing days and the optical density values at $750 \mathrm{~nm}\left(\mathrm{OD}_{750}\right)$ are shown along the $y$-axis. Data are means $\pm \mathrm{SE}, n=3$.

Significant $(p<0.05)$ differences in growth rates among chromium treatments for both microalgae species were observed. For M. pulchellum, control $\left(0 \mu \mathrm{g} \mathrm{L}^{-1}\right)$ and $50 \mu \mathrm{g} \mathrm{L}^{-1}$ chromium treatments showed exponential growth at $\mu=0.1912$ and $\mu=0.1605$, respectively, while the $\mathrm{Cr}(\mathrm{VI})$ induced inhibition of the PSII resulted in a pseudo substrate limited linear 
growth at $0.3688 \times 10^{6}\left(100 \mu \mathrm{g} \mathrm{L}{ }^{-1}\right.$ chromium $), 0.2139 \times 10^{6}\left(250 \mu \mathrm{g} \mathrm{L}^{-1}\right.$ chromium $)$ and $0.1311 \times 10^{6}\left(500 \mu \mathrm{g} \mathrm{L}^{-1}\right.$ chromium) cell per day. Furthermore, a significant reduction in growth rate was observed at $\mathrm{Cr}(\mathrm{VI})$ concentrations, $250 \mu \mathrm{g} \mathrm{L}^{-1}$ and $500 \mu \mathrm{g} \mathrm{L}^{-1}$, after day 10. At the given photon flux density, the control cultivation for M. pusillum was substrate limited and showed a linear growth at $0.6007 \times 10^{6}$ cells per day. Increasing concentrations of $\mathrm{Cr}(\mathrm{VI})$ decreased growth rates in a similar manner to $M$. pulchellum, with a growth rate of $0.4706 \times 10^{6}\left(50 \mu \mathrm{g} \mathrm{L}^{-1}\right.$ chromium $), 0.3937 \times 10^{6}\left(100 \mu \mathrm{g} \mathrm{L}^{-1}\right.$ chromium $), 0.168 \times 10^{6}$ $\left(150 \mu \mathrm{g} \mathrm{L}^{-1}\right.$ chromium) and $0.1110 \times 10^{6}\left(500 \mu \mathrm{g} \mathrm{L}^{-1}\right.$ chromium) cells per day (Table 1). The 50, 100 and $250 \mu \mathrm{g} \mathrm{L}^{-1}$ chromium treatments showed reduction in growth after day nine, while $500 \mu \mathrm{g} \mathrm{L}^{-1}$ chromium treatment showed reduction in growth rate and cell number after day 7.

Table 1. Effect of $\mathrm{Cr}(\mathrm{VI})$ on growth rates (cells/day).

\begin{tabular}{|c|c|c|c|c|c|}
\hline \multirow{2}{*}{ Species } & \multicolumn{5}{|c|}{$\mathrm{Cr}(\mathrm{VI})$ Concentration } \\
\hline & $0 \mu \mathrm{g} \mathrm{L}^{-1}$ & $50 \mu \mathrm{g} \mathrm{L}^{-1}$ & $100 \mu \mathrm{g} \mathrm{L}^{-1}$ & $250 \mu \mathrm{g} \mathrm{L}^{-1}$ & $500 \mu \mathrm{g} \mathrm{L}^{-1}$ \\
\hline $\begin{array}{l}\text { M. pulchellum } \\
\text { M. pusillum }\end{array}$ & $\begin{array}{c}\mu=0.1912 \\
0.6007 \times 10^{6} *\end{array}$ & $\begin{array}{c}\mu=0.1605 \\
0.4706 \times 10^{6} *\end{array}$ & $\begin{array}{l}0.3688 \times 10^{6 *} \\
0.3937 \times 10^{6 *}\end{array}$ & $\begin{array}{l}0.2139 \times 10^{6 *} \\
0.1678 \times 10^{6 *}\end{array}$ & $\begin{array}{l}0.1311 \times 10^{6 *} \\
0.1110 \times 10^{6 *}\end{array}$ \\
\hline
\end{tabular}

\subsection{Effect of Chromium on Modulated Fluorescence and Photosynthetic Inhibition}

The variations in quantum yield and photosynthetic inhibition of the tested microalgae cultures supplemented with different concentrations of $\mathrm{Cr}(\mathrm{VI})$ were studied for 11 days. Different $\mathrm{Cr}(\mathrm{VI})$ concentrations showed significant differences in fluorescence yield and photosynthetic inhibition. The significant $(p<0.05)$ increases in minimal $\left(F_{0}\right)$ and maximal $\left(F_{m}\right)$ fluorescence values were observed at $0 \mu \mathrm{g} \mathrm{L}{ }^{-1}-100 \mu \mathrm{g} \mathrm{L}{ }^{-1}$, however, a decline in $F_{0}$ and $F_{m}$ values was observed at $250 \mu \mathrm{g} \mathrm{L}^{-1}$ and $500 \mu \mathrm{g} \mathrm{L}^{-1}$ (Figures 3 and 4).

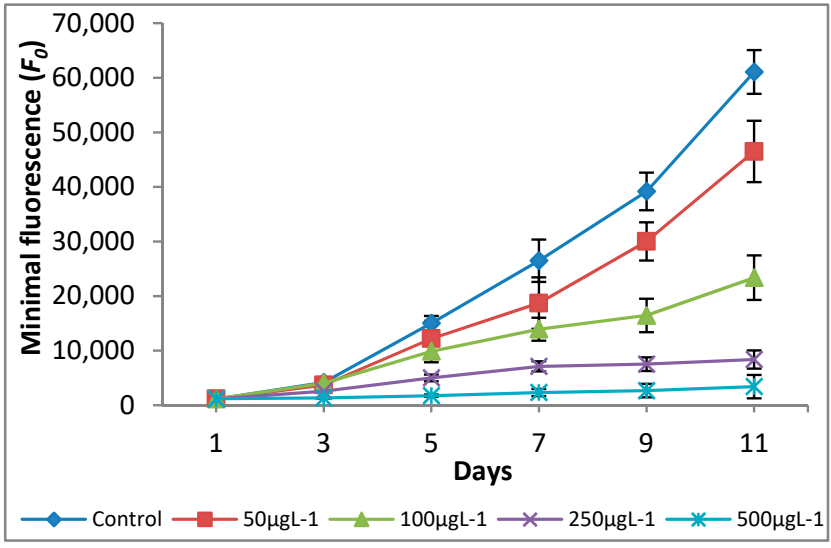

(a)

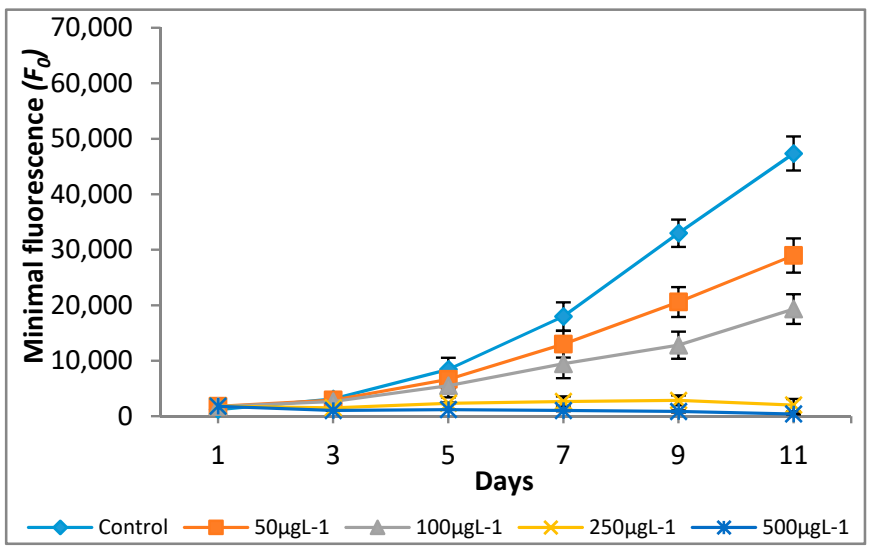

(b)

Figure 3. Effect of $\mathrm{Cr}(\mathrm{VI})$ on minimal fluorescence of (a) M. pulchellum and (b) M. pusillum. X-axis represents the culturing days, and the minimum fluorescence $\left(F_{0}\right)$ values are shown along the $y$-axis. Data are means $\pm \mathrm{SE}, n=3$.

A significant $(p<0.05)$ reduction in quantum yield $(Y)$ was noted at all the tested $\mathrm{Cr}(\mathrm{VI})$ concentrations as compared to the control $\left(0 \mu \mathrm{g} \mathrm{L}^{-1}\right.$; Figure 5$)$. It shows that chromium had a negative effect on the tested microalgae growth by interrupting photosynthesis. Both microalgae species showed a similar trend of photosynthetic inhibition at the tested $\mathrm{Cr}(\mathrm{VI})$ concentrations after day 3 of culturing and a maximum inhibition of up to $67 \%$, and $66 \%$ was observed for M. pulchellum and M. pusillum, respectively, at $500 \mu \mathrm{g} \mathrm{L}^{-1}$ (Figure 6). 


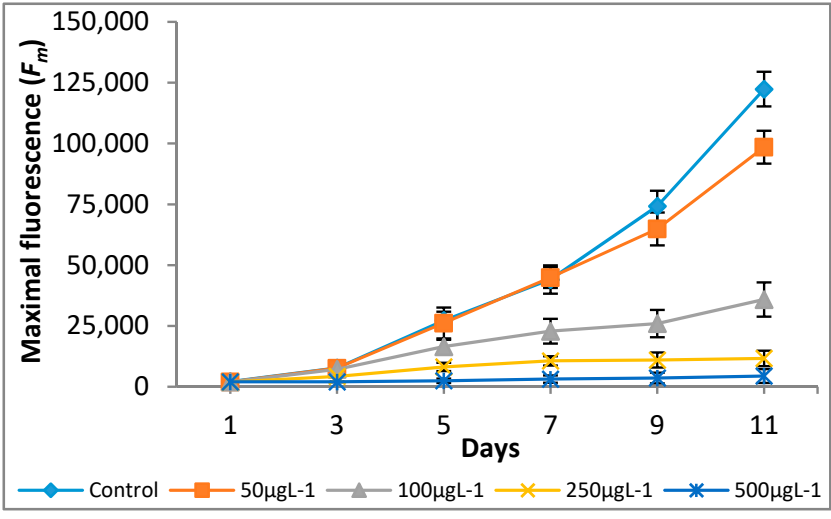

(a)

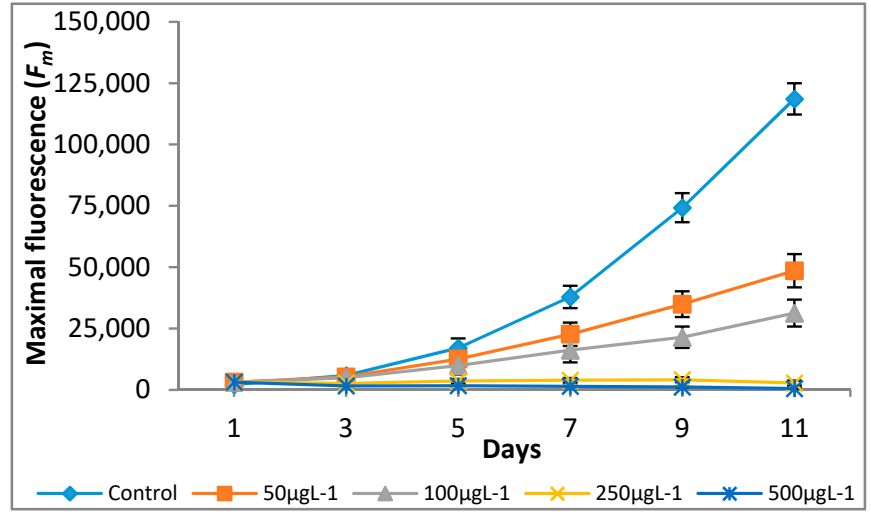

(b)

Figure 4. Effect of $\mathrm{Cr}(\mathrm{VI})$ on maximal fluorescence of (a) M. pulchellum and (b) M. pusillum. X-axis represents the culturing days, and the maximal fluorescence $\left(F_{m}\right)$ values are shown along the $y$-axis. Data are means $\pm \mathrm{SE}, n=3$.

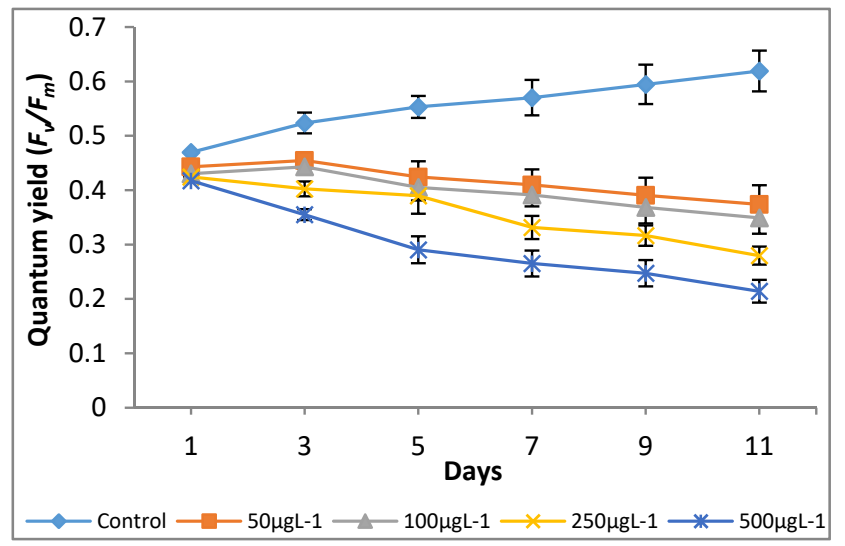

(a)

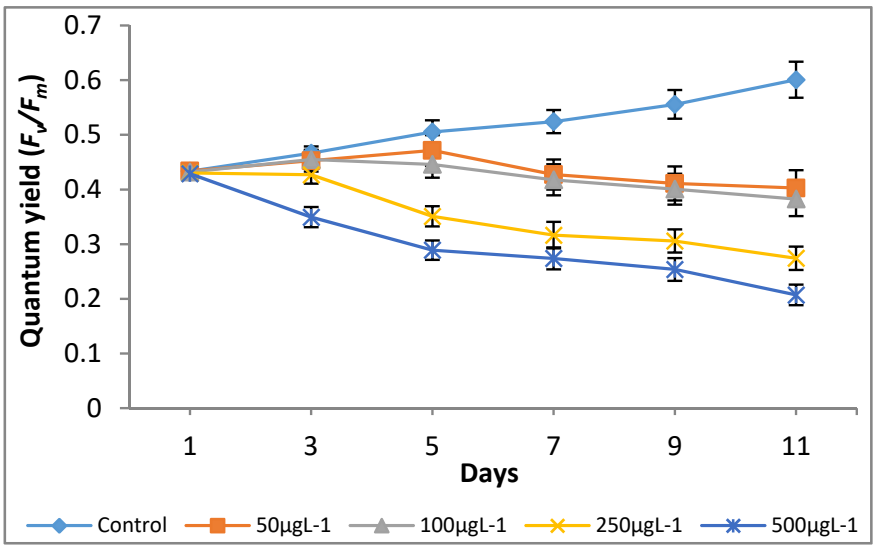

(b)

Figure 5. Effect of $\mathrm{Cr}(\mathrm{VI})$ on quantum yield of (a) M. pulchellum and (b) M. pusillum. X-axis represents the culturing days, and the quantum yield $(Y)$ values are shown along the $y$-axis. Data are means $\pm \mathrm{SE}, n=3$.

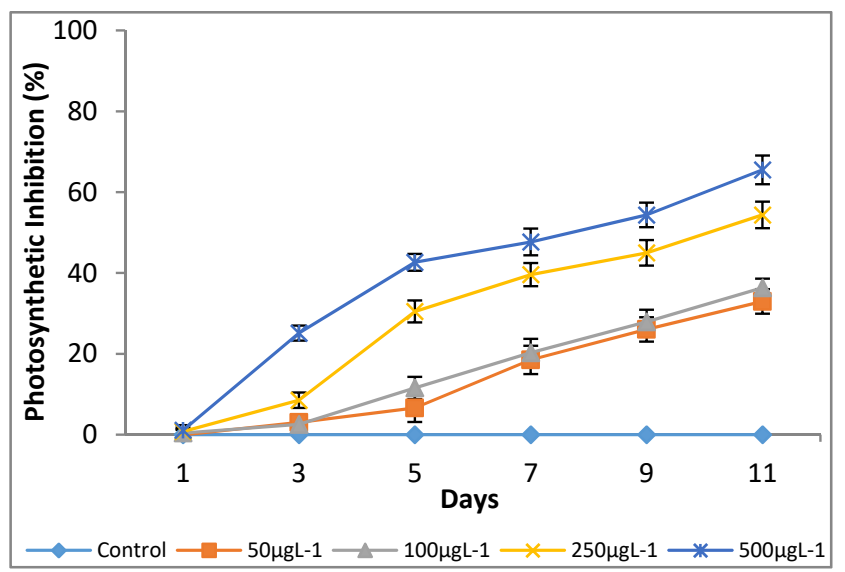

(a)

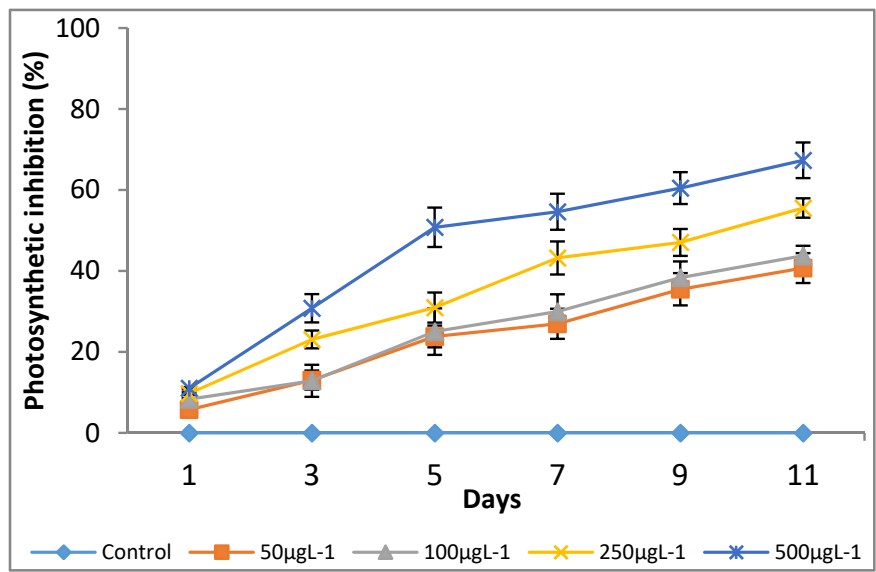

(b)

Figure 6. Effect of $\mathrm{Cr}(\mathrm{VI})$ on photosynthetic inhibition of (a) M. pulchellum and (b) M. pusillum. X-axis represents the culturing days, and the inhibition (\%) values are shown along the $y$-axis. Data are means $\pm \mathrm{SE}, n=3$. 


\subsection{Effect of Chromium on Lipid Accumulation}

The significant $(p<0.05)$ increases in lipid content were observed with the increasing $\mathrm{Cr}(\mathrm{VI})$ concentration in the culture medium. A lipid content of up to $36 \%$ was observed in M. pulchellum cultures at the maximum tested $\mathrm{Cr}(\mathrm{VI})$ concentration in this study $\left(500 \mu \mathrm{g} \mathrm{L}^{-1}\right)$, which was approximately 12 times higher than the control $\left(0 \mu \mathrm{g} \mathrm{L}^{-1}\right)$. Whereas a maximum lipid content of $30 \%$ was observed in M. pusillum cultures, which was approximately 3 times higher than the control. A drastic increase in $\mathrm{Cr}(\mathrm{VI})$ concentrationdependent lipid content was observed in M. pulchellum; however, the increase in concentration-dependent lipid content was not consistent in M. pusillum (Figure 7). However, both tested microalgae species showed significantly $(p<0.05)$ increased lipid content, which shows that the addition of chromium could significantly enhance the lipid accumulation in the tested freshwater microalgae species.

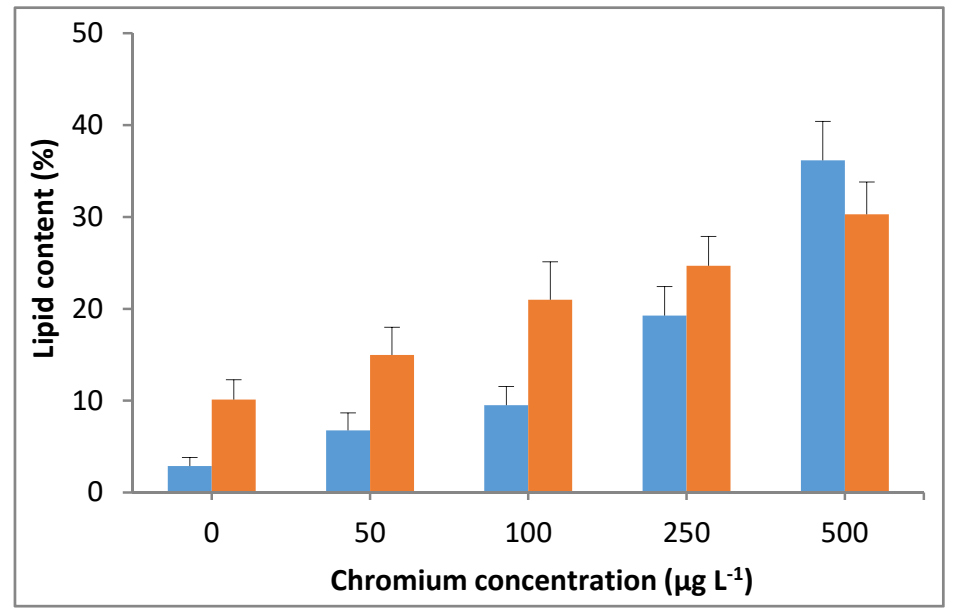

Figure 7. Effect of $\mathrm{Cr}(\mathrm{VI})$ on lipid content in M. pulchellum $(\square)$ and M. pusillum ( $\square)$. X-axis represents the chromium concentrations ( $\left.\mu \mathrm{g} \mathrm{L}^{-1}\right)$, and the lipid content (\%, $\mathrm{g}$ of lipid/g of dry weight biomass) is shown along the $y$-axis. Data are means $\pm \mathrm{SE}, n=3$.

\subsection{Fatty Acid Composition}

The fatty acids were analyzed by GC, and the major fatty acid composition of both tested microalgae species included palmitic acid (16:0; hexadecanoic acid), palmitoleic acid (C16:1; $\omega-7)$, vaccenic acid (C18:1; $\omega-7)$, linoleic acid (C18:2; $\omega-6), \alpha$-linoleic acid $(\mathrm{C} 18: 3 ; \omega-3)$ and arqachidonic acid $(\mathrm{C} 20: 4 ; \omega-6)$ as shown in Figure 8 . Higher levels of palmitic acid and $\alpha$-linoleic acid were observed in both microalgae cultures at all the tested concentrations. Higher $\mathrm{Cr}(\mathrm{VI})$ concentrations in M. pulchellum cultures resulted in slightly higher content of palmitic acid among the major fatty acids. However, all other fatty acids showed a slightly decreasing tendency at higher concentrations. The increasing $\mathrm{Cr}(\mathrm{VI})$ concentrations in M. pusillum cultures showed a slightly higher content of vaccenic acid and $\alpha$-linoleic acid. However, a slightly decreasing tendency was observed for palmitoleic acid and arachidonic acid. Furthermore, higher tested $\mathrm{Cr}(\mathrm{VI})$ concentrations $\left(250 \mu \mathrm{g} \mathrm{L}{ }^{-1}\right.$ and $\left.500 \mu \mathrm{g} \mathrm{L}^{-1}\right)$ significantly $(p<0.05)$ reduced the linoleic acid content. 


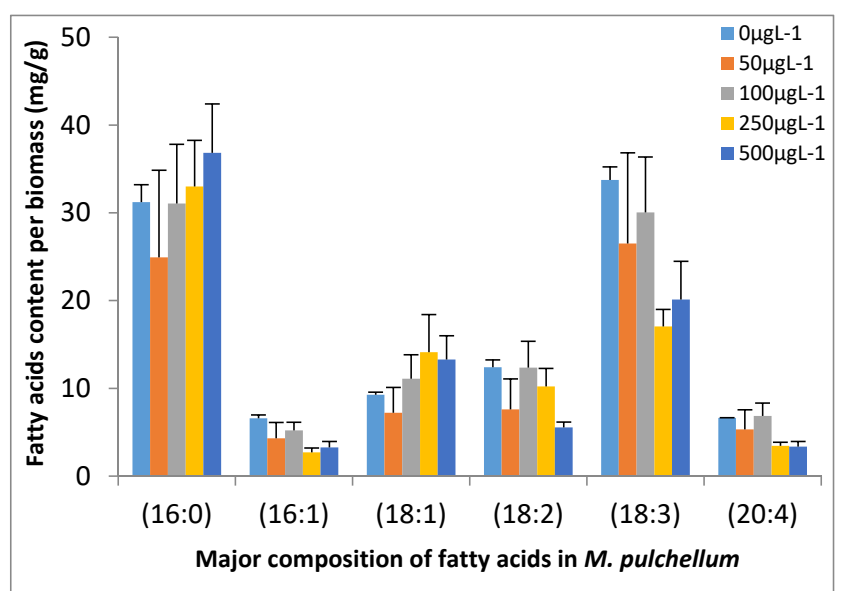

(a)

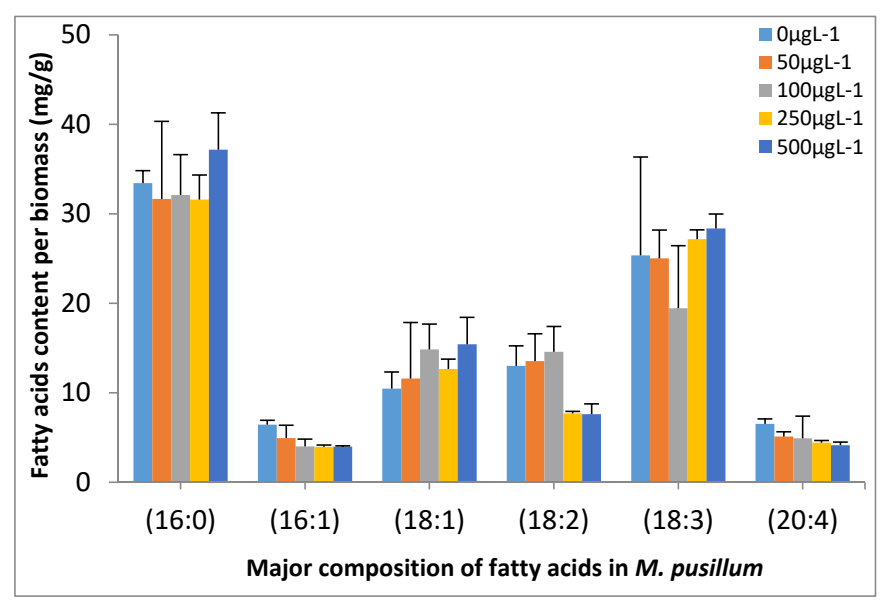

(b)

Figure 8. Effect of $\mathrm{Cr}(\mathrm{VI})$ on fatty acids composition in (a) M. pulchellum and (b) M. pusillum. X-axis represents the fatty acids, and fatty acid contents per biomass (mg/g) are shown along the $y$-axis. Data are means $\pm \mathrm{SE}, n=3$.

\section{Discussion}

Chromium exists in the environment as trivalent, $\mathrm{Cr}(\mathrm{III})$ and hexavalent form, $\mathrm{Cr}(\mathrm{VI})$, where $\mathrm{Cr}(\mathrm{VI})$ is the highly toxic, carcinogenic and mutagenic [29,30]. The discharge of chromium from anthropogenic sources such as household, industry, transport, mining and agriculture increases its concentration several times above normal levels [31]. The aquatic ecosystems are seriously affected by $\mathrm{Cr}(\mathrm{VI})$ toxicity, which depends on its physiochemical, oxidative and structural properties [32]. The $\mathrm{Cr}(\mathrm{VI})$ constituents are generally soluble and mobile in the environment [33]. They can easily pass cell membrane due to the structural similarity to inorganic anions which makes $\mathrm{Cr}(\mathrm{VI})$ an alternative substrate in the sulfate transport system [34,35]. The cytotoxic effects of $\mathrm{Cr}(\mathrm{VI})$ on living organisms including plants, animals and humans are well reported, and they are also a source of a variety of human cancers [32,36].

Heavy metal toxicity and the effect of heavy metals on microalgae have been extensively reported. However, there is a limited or no literature available on the heavy metal toxicity of economically promising freshwater eukaryotic microalgae species M. pulchellum and M. pusillum. The freshwater eukaryotic non-model microalgae species $M$. pulchellum and M. pusillum were chosen for this study due to their economic potential as they can grow at low light intensity as well as in $\mathrm{CO}_{2}$-deficient conditions [37]. They are diverse green phytoplankton species which occasionally inhabit freshwater lakes. Furthermore, the genetic transformation of M. pulchellum (formerly D. pulchellum) for higher erythropoietin protein accumulation was reported by our group [38], which shows the broad scope of this microalgae species. During this study, the toxicity of hexavalent chromium (0-500 $\left.\mu \mathrm{g} \mathrm{L}^{-1}\right)$ on M. pulchellum and M. pusillum was investigated by comparing variations in cell density, modulated fluorescence yield, relative photosynthetic inhibition and lipid accumulation. Both microalgae species exhibited significant sensitivities to the tested $\mathrm{Cr}(\mathrm{VI})$ concentrations as indicated by the fluorescence kinetics and lipid content.

Both microalgae species showed decreased growth at any $\mathrm{Cr}(\mathrm{VI})$ tested concentration when compared to the chromium free control cultivation. This effect has been previously attributed to the PSII inhibition via electron transport inhibition between $Q_{A^{-}}$and $Q_{B} / Q_{B^{-}}$ by the hexavalent chromium ion [39]. Additionally, higher tested concentrations showed a decline in growth after day 7, likely via the well elucidated genotoxic route, where chromium ions form complexes with nucleic acids, causing strand breaks and the formation of mutagenic Cr-DNA fragments. Similarly, significant increases in minimal $\left(F_{0}\right)$ and maximal $\left(F_{m}\right)$ fluorescence values were observed till $100 \mu \mathrm{g} \mathrm{L} \mathrm{L}^{-1}$; however, a decline in $F_{0}$ and $F_{m}$ values was observed at concentrations exceeding $100 \mu \mathrm{g} \mathrm{L}^{-1}$. Furthermore, $50 \mu \mathrm{g} \mathrm{L}^{-1}$ chromium treatment showed higher maximal fluorescence in M. pulchellum 
as compared to M. pusillum, which shows higher sensitivity of M. pusillum to chromium even at low concentration. All tested $\mathrm{Cr}(\mathrm{VI})$ concentrations showed a significant decline in quantum yield and photosynthetic inhibition as compared to the control. A maximum photosynthetic inhibition of up to $67 \%$ was observed in M. pulchellum at $500 \mu \mathrm{g} \mathrm{L}-1$ whereas M. pusillum showed a maximum photosynthetic inhibition of up to $66 \%$. This shows that $\mathrm{Cr}(\mathrm{VI})$ has a negative effect on normal growth of both microalgae species by interrupting photosynthesis.

Interestingly, both tested microalgae species showed quit similar trends for growth and fluorescence yields; this could be because both microalgae are freshwater eukaryotic microalgae species and belong to a same taxon-Chlorophyta-and thus showed similar $\mathrm{Cr}(\mathrm{VI})$ uptake and a similar PSII structure. Contrary to the present study, a 50\% inhibition in growth was observed by Hörcsik et al. [40] when analyzing $\mathrm{Cr}$ (VI) toxicity using chlorophyll composition of Auxenochlorella pyrenoidosa (Chlorella pyrenoidosa) for $72 \mathrm{~h}$ in media supplemented with $2 \mathrm{mg} \mathrm{L}^{-1}$ of $\mathrm{Cr}(\mathrm{VI})$ [40]. Similarly, in another study, a very minor amount of $\mathrm{Cr}(\mathrm{VI}), 5 \mu \mathrm{mol} \mathrm{L}{ }^{-1}$, showed up to $40 \%$ inhibition in the maximal quantum yield of PSII of Chlorella vulgaris when treated for $96 \mathrm{~h} \mathrm{[12].} \mathrm{The} \mathrm{variation} \mathrm{in} \mathrm{the} \mathrm{present} \mathrm{study}$ could be due to different microalgae species and different experimental conditions.

The lipid accumulation results were quite interesting; both tested microalgae showed increases in lipid content. A lipid content of up to $36 \%$ was observed in M. pulchellum at the maximum tested $\mathrm{Cr}(\mathrm{VI})$ concentration in this study $\left(500 \mu \mathrm{g} \mathrm{L}^{-1}\right)$, which was approximately 10 times higher than the control. Whereas a maximum lipid content of up to $30 \%$ was observed in M. pusillum. The fatty acids composition analysis showed higher levels of polyunsaturated fatty acids (hexadecenoic acid) and saturated fatty acids ( $\omega 3, \omega 6$, and $\omega 7$ ). However, chromium exposure significantly affected the saturated fatty acids content. In this study, linoleic acid (C18:2; $\omega 6)$ and $\alpha$-linoleic (C18:3; $\omega 3)$ were among the mostly affected fatty acids by $\mathrm{Cr}(\mathrm{VI})$. This agrees with the previously reported studies of Barsanti et al. [41] and Rochhetta et al. [42], which states that chloroplast structure related lipids such as linoleic acid and $\alpha$-linoleic are mostly affected by chromium. Furthermore, $\mathrm{Cr}(\mathrm{VI})$ treated cultures showed no significant differences for the non-photosynthetic structure related fatty acids such as arachidonic acid (C20:4; w6), which agrees with Rochhetta et al. [42]. This suggests that chloroplasts would be the main target organelle of $\mathrm{Cr}(\mathrm{VI})$ toxicity in M. pulchellum and M. pusillum.

Despite significant decreases in observed saturated fatty acids content at higher $\mathrm{Cr}(\mathrm{VI})$ concentration (especially $\omega 3$ and $\omega 6$ ), total lipid content showed a significant increase. This could be a microalgal defense mechanism to counteract oxidative damage [42]. Both microalgae species showed higher lipid accumulation at higher tested $\mathrm{Cr}(\mathrm{VI})$ concentration than the control; this shows that the addition of $\mathrm{Cr}(\mathrm{VI})$ could significantly enhance the lipid accumulation in M. pulchellum and M. pusillum.

The results of this study indicate that $\mathrm{Cr}(\mathrm{VI})$ can affect total lipids and fatty acids content, especially affecting the fatty acids related to photosynthetic activity. Changes in fatty acids composition in the treated cells could be due to their defense mechanism to reduce cellular damage caused by $\mathrm{Cr}(\mathrm{VI})$ and its route outlined above. Additionally, intracellular $\mathrm{Cr}(\mathrm{VI})$ reduction consumes intracellular antioxidants which could induce synthesis of simple and poly-unsaturated fatty acids as a defense mechanism. However, further analytical and biochemical analyses are necessary to assist the findings. The present study could aid in aquaculture industry, in maintenance of microalgae stock cultures and in estimating the possible side effects of using hexavalent chromium in microalgae cultures. It can further aid in the design and construction of biomarkers using eukaryotic freshwater microalgae species.

Author Contributions: Conceptualization, K.M.I.B.; methodology, K.M.I.B. and H.-J.L.; software, K.M.I.B. and H.-J.L.; validation, K.M.I.B., S.M. and A.J.; formal analysis, K.M.I.B. and H.-J.L.; resources, M.-G.C.; data curation, K.M.I.B. and H.-J.L.; writing-original draft preparation, K.M.I.B. and S.M.; writing-review and editing, S.M., A.J. and M.-G.C.; visualization, K.M.I.B. and H.-J.L.; su- 
pervision, M.-G.C.; project administration, M.-G.C. All authors have read and agreed to the published version of the manuscript.

Funding: This research was funded by Busan Metropolitan City, BB21+ 2020 grant. The APC was funded by BB21+ 2020 grant.

Institutional Review Board Statement: Not applicable.

Informed Consent Statement: Not applicable.

Data Availability Statement: The data generated or analyzed during this study are included in this article, and the primary data could be provided by the corresponding author upon request.

Acknowledgments: This work was supported by the BB21+ Project in 2020; authors are thankful for their support.

Conflicts of Interest: The authors declare no conflict of interest. The funders had no role in the design of the study; in the collection, analyses or interpretation of data; in the writing of the manuscript or in the decision to publish the results.

\section{References}

1. Bashir, K.M.I.; Mansoor, S.; Kim, N.-R.; Grohmann, F.R.; Shah, A.A.; Cho, M.-G. Effect of organic carbon sources and environmental factors on cell growth and lipid content of Pavlova lutheri. Ann. Microbiol. 2019, 69, 353-368. [CrossRef]

2. Lu, C.M.; Chau, C.W.; Zhang, J.H. Acute toxicity of excess mercury on the photosynthetic performance of cyanobacterium, Spirulina platensis-Assessment by chlorophyll fluorescence analysis. Chemosphere 2000, 41, 191-196. [CrossRef]

3. Juneau, P.; Dewez, D.; Matsui, S.; Kim, S.G.; Popovic, R. Evaluation of different algal species sensitivity to mercury and metolachlor by PAM-fluorometry. Chemosphere 2001, 45, 589-598. [CrossRef]

4. Pena-Vazquez, E.; Perez-Conde, C. Development of a microalgal PAM test method for Cu (II) in water: Comparison of using spectrofluorometry. Ecotoxicology 2010, 19, 1059-1065. [CrossRef] [PubMed]

5. Bashir, K.M.I.; Cho, M.-G. The effect of kanamycin and tetracycline on growth and photosynthetic activity of two Chlorophyte algae. BioMed Res. Int. 2016, 2016, 5656304. [CrossRef] [PubMed]

6. Miazek, K.; Iwanek, W.; Remacle, C.; Richel, A.; Goffin, D. Effect of metals, metalloids and metallic nanoparticles on microalgae growth and industrial product biosynthesis: A review. Int. J. Mol. Sci. 2015, 16, 23929-23969. [CrossRef] [PubMed]

7. Lopez-Rodas, V.; Agrelo, M.; Carrillo, E.; Ferrero, L.; Larrauri, A.; Martín-Otero, L.; Costas, E. Resistance of microalgae to modern water contaminants as the result of rare spontaneous mutations. Eur. J. Phycol. 2001, 36, 179-190. [CrossRef]

8. Hawrot-Paw, M.; Koniuszy, A.; Gałczyńska, M. Sustainable production of Monoraphidium microalgae biomass as a source of bioenergy. Energies 2020, 13, 5975. [CrossRef]

9. Bengtson Nash, S.M.; Quayle, P.A.; Schreiber, U.; Müller, J.F. The selection of a model microalgal species as biomaterial for a novel aquatic phytotoxicity assay. Aquat. Toxicol. 2005, 72, 315-326. [CrossRef]

10. Herlory, O.; Bonzom, J.M.; Gilbin, R. Sensitivity evaluation of green alga Chlamydomonas reinhardtii to uranium by pulse amplitude modulated (PAM) fluorometry. Aquat. Toxicol. 2013, 140-141, 288-294. [CrossRef]

11. Kumar, K.S.; Dahms, H.-U.; Lee, J.-S.; Kim, H.C.; Lee, W.C.; Shin, K.-H. Algal photosynthetic responses to toxic metals and herbicides assessed by chlorophyll a fluorescence. Ecotoxicol. Environ. Saf. 2014, 104, 51-71. [CrossRef]

12. Ouyang, H.L.; Kong, X.Z.; He, W.; Qin, N.; He, Q.S.; Wang, Y.; Wang, R.; Xu, F.L. Effects of five heavy metals at sub-lethal concentrations on the growth and photosynthesis of Chlorella vulgaris. Chin. Sci. Bull. 2012, 57, 3363-3370. [CrossRef]

13. Fu, F.; Wang, Q. Removal of heavy metal ions from wastewaters: A review. J. Environ. Manag. 2011, 92, 407-418. [CrossRef] [PubMed]

14. Siddiquee, S.; Rovina, K.; Azad, S.A.; Naher, L.; Suryani, S.; Chaikaew, P. Heavy metal contaminants removal from wastewater using the potential filamentous fungi biomass: A review. J. Microb. Biochem. Technol. 2015, 7, 384-393. [CrossRef]

15. Ng, C.C.; Motior Rahman, M.; Boyce, A.N.; Abas, M.R. Heavy metals phyto-assessment in commonly grown vegetables: Water spinach (I. aquatica) and okra (A. esculentus). SpringerPlus 2016, 5, 469. [CrossRef] [PubMed]

16. Vignati, D.A.L.; Dominik, J.; Beye, M.L.; Pettine, M.; Ferrari, B.J.D. Chromium (VI) is more toxic than chromium (III) to freshwater algae: A paradigm to revise? Ecotoxicol. Environ. Saf. 2010, 73, 743-749. [CrossRef]

17. WHO. Chromium in Drinking-Water Background Document for Development of WHO Guidelines for Drinking-Water Quality; World Health Organization: Geneva, Switzerland, 2003; Available online: https://www.who.int/water_sanitation_health/dwq/ chemicals / chromium.pdf (accessed on 2 March 2021).

18. Yang, L.; Chen, P. Biosorption of hexavalent chromium onto raw and chemically modified Sargassum sp. Bioresour. Technol. 2008, 99, 297-307. [CrossRef] [PubMed]

19. An, M.; Gao, L.; Zhao, W.; Chen, W.; Li, M. Effects of nitrogen forms and supply mode on lipid production of microalga Scenedesmus obliquus. Energies 2020, 13, 697. [CrossRef]

20. Ismail, M.; Phang, S.-M.; Tong, S.-L.; Brown, M.T. A modified toxicity testing method using tropical marine microalgae. Environ. Monit. Assess 2002, 75, 145-154. [CrossRef] 
21. Baumann, H.A.; Morrison, L.; Stenge, D.B. Metal accumulation and toxicity measured by PAM-chlorophyll fluorescence in seven species of marine macroalgae. Ecotoxicol. Environ. Saf. 2009, 72, 1063-1075. [CrossRef] [PubMed]

22. Bashir, K.M.I.; Lee, J.-H.; Petermann, M.J.; Shah, A.A.; Jeong, S.-J.; Kim, M.-S.; Park, N.G.; Cho, M.-G. Estimation of antibacterial properties of Chlorophyta, Rhodophyta and Haptophyta microalgae species. Microbiol. Biotechnol. Lett. 2018, 46, 225-233. [CrossRef]

23. Watanabe, M.M.; Kawachi, M.; Hiroki, M.; Kasai, F. NIES Collection List of Strains. In Microalgae and Protozoa. Microbial Culture Collections, 6th ed.; National Institute for Environmental Studies: Tsukuba, Japan, 2000; p. 159.

24. Schreiber, U. Detection of rapid induction kinetics with a new type of high-frequency modulated chlorophyll fluorometer. Photosynth. Res. 1986, 9, 261-272. [CrossRef] [PubMed]

25. Genty, B.; Briantais, J.-M.; Baker, N.R. The relationship between the quantum yield of photosynthetic electron transport and quenching of chlorophyll fluorescence. Biochim. Biophys. Acta Gen. Subj. 1989, 990, 87-92. [CrossRef]

26. Bligh, E.G.; Dyer, W.J. A rapid method of total lipid extraction and purification. Can. J. Biochem. Physiol. 1959, 37, 911-917. [CrossRef] [PubMed]

27. Ichihara, K.; Fukubayashi, Y. Preparation of fatty acid methyl esters for gas-liquid chromatography. J. Lipid Res. 2010, 51, 635-640. [CrossRef] [PubMed]

28. Balan, R.; Suraishkumar, G.K. Simultaneous increases in specific growth rate and specific lipid content of Chlorella vulgaris through UV-induced reactive species. Biotechnol. Prog. 2014, 30, 291-299. [CrossRef] [PubMed]

29. Rai, R.; Eary, L.E.; Zachara, J.M. Environmental chemistry of chromium. Sci. Total Environ. 1989, 86, 15-23. [CrossRef]

30. Gomez, V.; Callao, M.P. Chromium determination and speciation since 2000. TRAC-Trend Anal. Chem. 2006, 25, 1006-1015. [CrossRef]

31. Nogales, B.; Lanfranconi, M.P.; Pina-Villalonga, J.M.; Bosch, R. Anthropogenic perturbations in marine microbial communities. FEMS Microbiol. Rev. 2011, 35, 275-298. [CrossRef] [PubMed]

32. Bagchi, D.; Stohs, S.J.; Downs, B.W.; Bagchi, M.; Preuss, H.G. Cytotoxicity and oxidative mechanisms of different forms of chromium. Toxicology 2002, 180, 5-22. [CrossRef]

33. Ertani, A.; Mietto, A.; Borin, M.; Nardi, S. Chromium in agricultural soils and crops: A review. Water Air Soil Pollut. 2017, 228, 190. [CrossRef]

34. Cieslak-Golonka, M. Toxic and mutagenic effects of chromium (VI). In Polyhedron Rep; Elsevier Science Ltd: Amsterdam, The Netherlands, 1996; Volume 61, p. 3667.

35. Haglund, K. The use of algae in aquatic toxicity assessment. In Progress in Phycological Research; Biopress: Bristol, UK, 1997; Volume 12, pp. 181-212.

36. Vajpayee, P.; Rai, U.N.; Ali, M.B.; Tripathi, V.; Yadav, V.; Sinha, S.; Singh, S.N. Chromium-induced physiologic changes in Vallisneria spiralis L. and its role in phytoremediation of tannery effluent. Bull. Environ. Contam. Toxicol. 2001, 67, 246-256. [CrossRef] [PubMed]

37. Irfanullah, H.M.D.; Moss, B. Ecology of Dictyosphaerium pulchellum Wood (Chlorophyta, Chlorococcales) in a shallow, acid, forest lake. Aquat. Ecol. 2006, 40,1-12. [CrossRef]

38. Bashir, K.M.I.; Kim, M.-S.; Stahl, U.; Cho, M.-G. Agrobacterium-mediated genetic transformation of Dictyosphaerium pulchellum for the expression of erythropoietin. J. Appl. Phycol. 2018, 30, 3503-3518. [CrossRef]

39. Pan, X.; Chen, X.; Zhang, D.; Wang, J.; Deng, C.; Mu, G.; Zhu, H. Effect of chromium(VI) on photosystem II activity and heterogeneity of Synechocystis sp. (Cyanophyta): Studied with in vivo chlorophyll fluorescence tests. J. Phycol. 2009, 45, 386-394. [CrossRef] [PubMed]

40. Hörcsik, Z.; Oláh, V.; Balogh, A.; Mészáros, I.; Simon, L.; Lakatos, G. Effect of Chromium(VI) on growth, element, and photosynthetic pigment composition of Chlorella pyrenoidosa. Acta. Biol. Szeged. 2006, 50, 19-23.

41. Barsanti, L.; Bastianini, A.; Passarelli, V.; Tredici, M.R.; Gualtieri, P. Fatty acid content in wild type and WZSL mutant of Euglena gracilis. J. Appl. Phycol. 2000, 12, 515-520. [CrossRef]

42. Rocchetta, I.; Mazzuca, M.; Conforti, V.; Ruiz, L.; Balzaretti, V.; Ríos de Molina, M.d.C. Effect of chromium on the fatty acid composition of two strains of Euglena gracilis. Environ. Pollut. 2006, 141, 353-358. [CrossRef] [PubMed] 